\title{
Disruption of DNA methylation via $S$-adenosylhomocysteine is a key process in high incidence liver carcinogenesis
}

\author{
Leda Mirbahai ${ }^{1}$, Tim D Williams ${ }^{1}$, Guangliang Yin², Andrew D Southam', Ulf Sommer ${ }^{3}$, Ning Li ${ }^{2}$, John P Bignell ${ }^{4}$, \\ Brett P Lyons ${ }^{4}$, Mark R Viant ${ }^{1,3}$, James K Chipman ${ }^{1 *}$ \\ From Birminghm Cancer Epigenetics Conference; Translational Opportunities \\ Birmingham, UK. 16 May 2013
}

Modifications in histologically normal tissue distal to tumours are increasingly evident and the role of such molecular events in tumour susceptibility or in response to presence of a tumour is unclear. We have exploited the ability to explain distal tissue modifications in the dab fish (Limanda limanda) which has an unprecedented high occurrence of hepatic adenoma (up to 20\%) when analysed from the natural environment. To investigate this, three tissue categories of hepatocellular adenoma, histologically normal liver tissue distal to tumours and livers of non-tumour-bearing dab were used. A multi"omics" approach was used to provide a comprehensive understanding of the key molecular abnormalities. A remarkable and consistent global hypomethylation, modification of $\mathrm{CpG}$ island methylation, gene expression and disruption of one-carbon metabolism was discovered in normal tissue distal to tumours compared to livers of non-tumour-bearing fish. The mechanism of this disruption is linked, not to depletion of $S$-adenosylmethionine, as is often a feature of mammalian tumours, but to a decrease in choline and elevated $S$-adenosylhomocysteine, a potent inhibitor of DNA methytransferase. This novel feature of normal-appearing tissue of tumour-bearing fish helps to understand the unprecedentedly high incidence of tumours in fish sampled from the field and adds weight to the controversial epigenetic progenitor model of tumourigenesis.

\footnotetext{
* Correspondence: j.k.chipman@bham.ac.uk

${ }^{1}$ School of Biosciences, University of Birmingham, Edgbaston, Birmingham, UK

Full list of author information is available at the end of the article
}

\section{Authors' details}

${ }^{1}$ School of Biosciences, University of Birmingham, Edgbaston, Birmingham, UK. ${ }^{2}$ Beijing Institute of Genomics, Chinese Academy of Sciences, Beijing 100029, China. ${ }^{3}$ NERC Biomolecular Analysis Facility - Metabolomics Node (NBAF-B), School of Biosciences, University of Birmingham, Edgbaston, Birmingham, UK. ${ }^{4}$ Cefas, Weymouth Laboratory, Weymouth, Dorset, UK.

Published: 19 August 2013

\section{doi:10.1186/1868-7083-5-S1-S9}

Cite this article as: Mirbahai et al:: Disruption of DNA methylation via $S$-adenosylhomocysteine is a key process in high incidence liver carcinogenesis. Clinical Epigenetics 2013 5(Suppl 1):S9.
Submit your next manuscript to BioMed Central and take full advantage of:

- Convenient online submission

- Thorough peer review

- No space constraints or color figure charges

- Immediate publication on acceptance

- Inclusion in PubMed, CAS, Scopus and Google Scholar

- Research which is freely available for redistribution

Submit your manuscript at www.biomedcentral.com/submit
() Biomed Central

\section{Biomed Central}

